\title{
Regulation and Civil Liability Under the California Corporate Securities Act: IV
}

\author{
T.W. Dahlquist*
}

\begin{abstract}
This is the fourth and last of the series of articles published under the above title.t
\end{abstract}

\section{DEFENSES}

General.

The prohibitions and penalties of the Act are leveled solely against the seller and not against the buyer. Liability is imposed on the seller regardless of fault on his part, and, generally speaking, regardless of reliance or knowledge of the buyer. The liability is essentially absolute in its nature. Scienter, reliance, materiality and causation, in general, are irrelevant.

Nevertheless, considerations of scienter, reliance, privity, and causation undoubtedly influence the courts in making various decisions under the Act. They apparently find it difficult to apply rigidly, and blindly, under all circumstances, such a stern rule of absolute liability. Here also the pragmatic approach of the courts to the entire problem is evident. Thus, despite the paramount policy of the Act in protecting the purchaser vis-à-vis the issuer, the courts seem to be not unmindful of the fact that buyers themselves are not always wholly blameless. Buyers of securities, as well as sellers, are sometimes motivated by avarice and speculative greed, and they should not be permitted to use the Act as a vehicle of unconscionable conduct on their part. Such considerations have undoubtedly influenced the courts in many cases.

While the Act is a paternalistic act even designed to guard investors from their own folly, the cases recognize that there is a limit beyond which they should not go in protecting buyers. Thus the supreme court stated, in Pollak v. Staunton," that there is a "border line which courts will not cross in an effort to give assistance to those who have heedlessly followed the phantom of speculation into questionable realms."

\footnotetext{
*A.B., J.D., University of California; member of the California Bar.

†Previous articles appeared in (1945) 33 CALIF. L. Rev. 343; (1946) 34 ibid. 344, 543.
}

1 (1930) 210 Cal. 656, 666, 293 Pac. 26, 30. 
Reliance, generally, is not an essential element. Nevertheless, a buyer's conduct after acquiring full knowledge of the violation may bar affirmative relief. ${ }^{2}$ And while causation is generally not required to impose liability under the Act, nevertheless the courts have been influenced by a lacis of causation in the determination of some of the questions arising under the Act. Thus in Fox-Woodsum Lumber Co. v. Bank of America, ${ }^{3}$ where there was a complete absence of fraud, the supreme court stated:

" :.. There is no causal connection whatever between the failure to obtain a permit from the commissioner of corporations and whatever loss was suffered .... The actual cause of the loss ... was entirely extraneous to the lack of the permit, such as shrinkage in the value of the mortgaged property inciclent to the depression rendering a second lien of little value. If a permit had been obtained the shrinkage and loss would have occuried in precisely the same manner and to the same extent that it did occur, and the presence of a permit would not have obviated the loss."

Furthermore, unconscionable delay on the part of buyers, permitting an opportunity for speculation to the possible injury of the seller, may bar recovery. Thus, in Brewis v. Toffelmier ${ }^{4}$ the court stated:

"Where a plaintiff, instead of availing himself of so plain a remedy as rescission, retains the property, and waits more than three years, possibly to see the outcome of the venture, ... the equities cannot be said to unquestionably favor going to the extent asked ...." (That is, permit recovery for damages without rescission where stock was actually issued and existent and presumptively worth what was paid for it.)

And in Robbins v. Pacific Eastern Corporation, the supreme court stated:

"... plaintiffs, and the other stockholders, got exactly what they wanted and what they bargained for--where no fraud or imposition has been proved-and ... they are now trying to recoup their losses, by a strained and technical construction of the contract, from what turned out to be a bad bargain."

Also, while scienter is not required to impose liability under the Act, the element of scienter is determinative as to the period of limi-

\footnotetext{
2 First Nat. Bk. v. Thompson (1931) 212 Cal. 388, 298 Pac. 808.

3 (1936) 7 Cal. (2d) 14, 17, 59 P. (2d) 1019, 1020.

4 (1929) 97 Cal. App. 329, 338, 275 Pac. 819, 823.

5 (1937) 8 Cal. (2d) $241,273,65$ P. (2d) $42,59$.
} 
tations under the present rule announced by the supreme court, as hereinafter shown.

Accordingly, it is clear that the elements of scienter, reliance, causation, and even privity, are not wholly eliminated for all purposes. The absence of any one or more of these elements may have some bearing on the question of defenses.

\section{Pari delicto rule.}

Under a statute under which the parties are in pari delicto and equally within its prohibition, executed transactions stand and executory contracts are invalid; neither party can obtain affirmative relief because of the policy against aiding one who has done a wrong to the public. The law washes its hands of both parties. However, if the parties are not in pari delicto, a buyer who does not participate in the wrongdoing may rescind even a completely executed purchase in which the seller violated the statute.

It was early held that the parties are not in pari delicto under the Act since the prohibitions and penalties of the Act are leveled against the seller and not against the buyer and the Act is designed to protect buyers from sellers. Nevertheless, there is a great amount of confusion in the early cases. In the rather early case of Domenigoni $v$. Imperial Live Stock Company ${ }^{6}$ a purchaser who was a party to the permit sought to cancel notes given in payment for stock where the permit prescribed cash. The supreme court denied relief on the grounds that the buyer had knowingly violated the conditions of the permit and that his action constituted a fraud on other buyers, and he was held to have aided the issuer and to be himself a fraud-feasor and therefore in pari delicto. In the often-quoted case of Tatterson $v$. $K e h r l e i n{ }^{7}$ the court applied the rule that a buyer is not in pari delicto, and distinguished the Domenigoni case, holding that the rule of that case must be limited to its facts. Subsequently, in Michell v. Grass Valley Gold Mines Co., ${ }^{8}$ the supreme court held the plaintiff to be in pari delicto apparently on the ground that both the issuing corporation and the buyer acted on advice of counsel that it was not necessary to obtain a permit. The case of Hemmeon v. Amalgamated Copper Mines Co. ${ }^{9}$ seemed to establish the rule that a buyer would be

\footnotetext{
6 (1922) 189 Cal. 467, 209 Pac. 36.

7 (1927) 88 Cal. App. 34, 263 Pac. 285.

8 (1929) 206 Cal. 609, 275 Pac. 418.

9 (1928) 95 Cal. App. 400, 273 Pac. 74.
} 
held to be in pari delicto if he had knowledge of violation of the Act by the corporation.

However, the later cases show a marked tendency to narrow the rule of the Domenigoni and Michell cases, and to protect the buyer unless he actively participates in some manner in the issue, or is equally culpable. Attempts have been made to explain the holdings in the Domenigoni and Michell cases on the basis that "less degree of culpability may be sufficient where the rights of innocent third parties have intervened", ${ }^{10}$ but this explanation is not entirely convincing. In any event, it is now well established that mere knowledge on the part of the buyer of the violation of the Act is not sufficient to place him in pari delicto. Thus, in the federal case of In re Builders' Finance Association, Inc., ${ }^{11}$ a case in bankruptcy, the court held that even though the buyer was aware of a permit violation (having given property for stock when the permit authorized a sale for cash only) he was not equally culpable with the issuer and was therefore not in pari delicto. The court stated:

"The provisions of the Blue Sky Law requiring that corporate securities be sold in strict conformity with the permit of the commissioner of corporations is for the benefit of the public, so as to prevent the sale by corporations and their agents of spurious and illegal stock and to safeguard the purchasers against the perpetration of fraud by the seller in corporate stock sales. There is nothing in the agreed facts of this matter that justifies an inference or finding that the purchasers were perpetrating or attempting to perpetrate any fraud upon the corporation or anyone .... While they may be in delicto with the corporation their wrong is not of equal degree with it.

"... if the rule contended for by the association were applied in this matter such application would defeat the very purpose which the Legislature must have had in mind in enacting the Blue Sky Law."

The holding of this federal case has subsequently been fully recognized by the California supreme court. In the leading case of Randall v. California Land Buyers Syndicate ${ }^{12}$ it was held that the parties are not in pari delicto since the statute is for the benefit and protection of the buyer and the penalties prescribed by the Act are all laid on the seller. The buyer seeking affirmative relief will be denied relief only

10 Miller v. California Roofing Co. (1942) 55 Cal. App. (2d) 136, 144, 130 P. (2d) 740, 745; California Western Holding Co. v. Merrill (1935) 7 Cal. App. (2d) 131, 46 P. (2d) 175 .

11 (S.D. Cal. 1928) 26 F. (2d) 123, 125.

12 (1933) 217 Cal. 594, 20 P. (2d) 331. 
where the record shows that he is equally culpable with the seller..$^{13}$ Mere knowledge of the terms of the permit or lack of a permit are not alone sufficient to raise the guilt of the purchaser or subscriber to that degree. In the Randall case the permit permitted sales for cash only. The buyer had seen a copy of the permit and knew that property was to be taken in exchange for stock in violation of the permit. The Randall case is now recognized as the leading case as to the applicability of the pari delicto rule and has been followed by imnumerable subsequent cases. ${ }^{14}$ Since actual knowledge of the violation alone is not sufficient to place the buyer in pari delicto, a fortiori the buyer is not in pari delicto though the means of obtaining knowledge are readily available to him. He is not charged with notice of the public records in the office of the Corporation Commissioner. ${ }^{15}$

Thus, it is well established that reliance is generally not an element of liability under the Act. Knowledge on the part of the buyer of a violation does not of itself constitute a defense, even though the buyer be an incorporator and director. There must be some active conduct of the buyer coupled with his knowledge, and usually the rights of innocent third parties must intervene. The buyer will not be held to be in pari delicto unless he is equally culpable with the seller, ${ }^{16}$ or unless he has full knowledge and connives with the seller to violate the Act, ${ }^{17}$ or unless there is a conspiracy or intent to defraud and evade the Act or the terms of the permit actually issued in which the purchaser participates, or there are other reasons making it inequitable to grant relief. ${ }^{18}$ However, as previously stated, while knowledge will not preclude the availability of the violation as a defense, it may under certain circumstances bar the buyer from affirmative relief. ${ }^{19}$

13 Any officer or director purchasing the security who authorized and participated in illegal issue is in pari delicto. Bliss v. California Coop. Prod. (1937) 23 Cal. App. (2d) 245, 72 P. (2d) 885; Regan v. Albin (1933) 219 Cal. 357, 26 P. (2d) 475.

14 See, particularly, Holinquist v. Kent (1933) 219 Cal. 231, 25 P. (2d) 977; Duntley v. Kagarise (1935) 10 Cal. App. (2d) 394, 52 P. (2d) 560.

15 MacDonald v. Reich \& Lievre, Inc. (1929) 100 Cal. App. 736, 281 Pac. 106; of. Mary Pickford Co. v. Bayly Bros., Inc. (1939) 12 Cal. (2d) 501, 86 P. (2d) 102.

16 Caunpbell v. Julian Merger Mines (1931) 111 Cal. App. 649, 295 Pac. 1040.

17 Western Oil Etc. Co. v. Venago Oil Corp. (1933) 218 Cal. 733, 24 P. (2d) 971; see also, Eberhard v. Pacific Southwest L. \& M. Corp. (1932) 215 Cal. 226, 9 P. (2d) 302 ; National Bk. v. J. G. Ruddle Properties, Inc. (1933) 218 Cal. 435, 23 P. (2d) 1016.

18 Dounestic \& Foreign Pet. Co., Ltd. v. Long (1935) 4 Cal. (2d) 547, 51 P. (2d) 73 (one of assignes beld to be in pari delicto with issuers because he had been both assignor and assignee).

19 First Nat. Bk. v. Thompson, supra note 2. 


\section{Subsequent validation, ratification and estoppel.}

Since the security issued in violation of the permit provisions of the Act is itself invalid by reason of the voiding section, and with it the contract of purchase, there can be no estoppel or ratification between the immediate parties to it. The doctrines and defenses of estoppel, waiver and ratification have no application to contracts which are void and not merely voidable. ${ }^{20}$ The rule is clearly stated in the leading case of Walker v. Harbor Realty Etc. Corp. ${ }^{21}$ in which the court said:

"None of the testimony in the record nor any of the evidence offered
by the defendants has the effect to take this case out of the general
rule ... that the doctrines of estoppel by conduct and ratification
have no application to a contract which is void, as in the present case,
because it violates an express mandate of the law or the dictates of
public policy; and the statute being for the protection of the buyer
of corporate securities and the penalties prescribed for a violation
thereof being all laid upon the seller, the buyer is not in pari delicto
with the seller. No facts have been presented or offered which could
bring this case within the exceptions ... where rights of others than
the parties to the void sale or contract were involved and the buyer
had by his own conduct made himself answerable to the claims of such
third parties.... The present action involves the rights only of the
parties themselves."22

Or, as stated in a frequently quoted passage:

"Such a contract has no legal existence for any purpose and neither action nor inaction of a party to it can validate it and no conduct of a party to it can be invoked as an estoppel against asserting its invalidity."23

Even in cases involving creditors and receivers in actions to impose stockholders' liability, recovery will not be allowed if the corporation itself could not recover, ${ }^{24}$ and innocent investors are not estopped to show that their securities are void. However, if the in-

20 Tatterson v. Kehrlein, supra note 7.

21 (1931) 214 Cal. 46, 48, 3 P. (2d) 557.

22 The court cited Tatterson v. Kehrlein, supra note 7; Honn v. Hamer (1927) 81 Cal. App. 276, 253 Pac. 336; Reno v. American Ice Machine Co. (1925) 72 Cal. App. 409, 237 Pac. 784; Pollak v. Staunton, supra note 1, and First Nat. Bk. v. Thompson, supra note 2, for the general rule; and Moore v. Moffat (1922) 188 Cal. 1, 204 Pac. 220; Domemigoni v. Imperial Live Stock Co., supra note 6; and Michell v. Grass Valley Gold Mines Co., supra note 8, as noting the exceptions.

23 Reno v. American Ice Machine Co., supra note 22 at 413, 237 Pac. at 785.

24 Herkner v. Rubin (1932) 126 Cal. App. 677, 14 P. (2d) 1043; Regan v. Albin, supra note 13. 
vestors connive in the failure to comply with the permit, they will be estopped to show that they are in fact stockholders. ${ }^{25}$

A corporation may not assert the defense of estoppel or ratification in a foreclosure action when notes ${ }^{26}$ or bonds ${ }^{27}$ were issued without a permit, where to do so would be to permit it to take advantage of its own wrong.

Nevertheless, as heretofore stated, the general statements in several of the cases to the effect that there can be no ratification, under any circumstance, of a sale of securities issued in violation of the Act, and that the buyer of such securities is never estopped to assert the illegality thereof, are mere generalizations. It is true, generally, that conduct on the part of the buyer which would preclude his right to relief under the strict theory of rescission will not be held to operate as a ratification or work an estoppel. Thus, neither retention of dividends, ${ }^{28}$ continued payment of purchase price installments, ${ }^{29}$ attendance at directors' or stockholders' meetings ${ }^{30}$ attempts to compromise after knowledge of violation, ${ }^{31}$ nor an assertion of ownership of the securities $^{32}$ will operate as a ratification or estoppel; but conduct after discovery of the violation may under certain circumstances bar affirmative relief..$^{33}$ However, under the rule of the Eberhard and kindred cases, the security itself is void only at the behest of the buyer who, if he so elects, may validate the security to his own advantage. Therefore it is inaccurate to say that there can be no ratification under any circumstances. But in any event, the issuer can never invoke either ratification or estoppel to the prejudice of the purchaser unless such purchaser is equally culpable with the issuer.

\section{Statute of limitations.}

The Act contains no express period of limitations as do so many other state securities acts and the federal securities acts. Both the Securities Act of 1933 (section 13) and the Securities Exchange Act of 1934 [sections $9(\mathrm{e})$ and $18(\mathrm{c})$ ] provide that suits must be brought

25 Bliss v. California Coop. Prod., supra note 13.

28 Eberhard v. Pacific Southwest L. \& M. Corp., supra note 17.

$2 \pi$ National Bk. v. J. G. Ruddle Properties, Inc., supra note 17.

28 Regan v. Albin, supra note 13.

20 Reno v. American Ice Machine Co., supra note 23.

30 Walker v. Harbor Realty Development Co., supra note 21; Honn v. Hamer, supra note 22 .

31 First Nat. Bk. v. Thompson, supra note 2.

32 Pollak v. Staunton, supra note 1.

33 First Nat. Bk. v. Thompson, supra note 2. 
within one year after discovery and in no case can suit be brought after the expiration of three years.

There is of course no period for assertion of illegality defensively..$^{34}$

Some of the earlier cases in the lower appellate courts of California, which proceeded on the theory that an action for violation under the Act sounded basically in fraud, held that the action was not barred under any circumstances until three years after the buyer's discovery of the seller's lack of a permit. ${ }^{35}$ While the question was earlier presented to the California supreme court in a case which was determined on wholly different grounds, ${ }^{36}$ it was first squarely met by the supreme court in the leading case of Mary Pickford Co. v. Bayly Brothers, $I n c{ }^{37}$ That case expressly rejected the theory that fraud will be conclusively presumed under all circumstances where there is a violation of the Act. The court in that case stated the rule as follows:

"Whenever ... an issuer or underwriter of securities offers them for sale to the public, he impliedly represents that the applicable provisions of law have been complied with. The falsity of that representation may give rise to an action either for breach of warranty or for fraud depending upon the culpability of the seller in the particular transaction. 'The representation of fact which induces a bargain is a warranty. In truth, the obligation imposed upon the seller in sucl a case is imposed upon him not by virtue of his agreement to assume it, but because of a rule of law applied irrespective of agreement.' ... . The obligation of a warranty is absolute, and is imposed as a matter of law irrespective of whether the seller knew or should have known of the falsity of his representations. Fraud, on the other hand, involves the additional requirement that the seller knew, or, in the exercise of reasonable diligence should have known, that his representations were false....

"The allegations ... present facts showing a sale of securities upon an implied warranty which was untrue. That warranty was broken at the time of the sale and the statute of limitations commenced to run at that time.... The causes of action for breach of warranty were, therefore, barred long prior to the commencement of the action $\ldots .^{38}$

"... it is clear that a person who sells a security impliedly represents that a permit therefor has been secured when one is required by the Corporate Securities Act for such a sale. If this implied representa-

34 6A CAL. JUR. 503.

35 MacDonald v. Reich \& Lievre, Inc., supra note 15; Klombies v. Weeks Poultry Community (1932) 121 Cal. App. 175, 8 P. (2d) 940.

36 Young v. Three for One Oil Royalties (1934) 1 Cal. (2d) 639, 36 P. (2d) 1065.

37 Supra note 15.

38 Ibid. at 519, 86 P. (2d) at 111. 
tion is false, then it is a negligent misrepresentation which is an actionable fraud, and the buyer's right of action does not accrue until he discovers its falsity unless the seller acted upon information sufficient to justify a reasonable man in concluding that no permit was required. In that event there has been a breach of warranty, but no fraud, and the buyer's cause of action accrues at the date of the sale." 39

Also, in the companion case of Bartlett v. Suburban Estates, Inc., ${ }^{40}$ decided the same day as the Pickford case, the court restated the rule as follows:
"... the defendants cannot escape liability merely because they had no knowledge or information that a permit was required. As stated in the Pickford case, the issuance or sale of a security carries with it an implied representation that a permit therefor has been secured if one is required by the Corporate Securities Act. But where the seller acted upon information sufficient to justify a reasonable man in con- cluding that no permit was required, then he is not liable in fraud even though lie was mistaken in his belief.
"Therefore, in so far as the liability of the defendants in these ac- tions is concerned, as each of them was commenced more than six years after the sale of the securities, the plaintiffs cannot recover if the defendants acted upon information sufficient to justify a reason- able man in believing that a permit was not required. The question is not concluded by their honest opinion or by the fact that they had no knowledge that a permit was required, unless this opinion or knowledge was based upon information sufficient to justify a reason- able man in acting as they did. This is, of course, a question of fact."

In the Bartlett case, none of the plaintiffs relied upon or proved any representation concerning the validity of the securities sold other than those which may be implied from the issuance of the certificates representing the interests involved. Also, in that case the court below expressly found that none of the defendants in the action actually knew at the time the securities were issued that any permit was required; that, on the contrary, the agents and attorneys of the defendants in charge of the issuance of the securities were honestly of the opinion that no permit was required; and that neither the defendants nor their agents nor their attorneys had any knowledge or information that any permit required by law for the issuance of the securities had not been issued. Consequently, the supreme court reversed the judgment in favor of the plaintiffs in the Bartlett case.

39 Ibid. at 525, 86 P. (2d) at 114.

40 (1939) 12 Cal. (2d) 527, 530, 86 P. (2d) 117, 118. 
It will be observed that both the theory of liability and the rule as to the limitation of actions announced in the two cases is highly involved. An attempt will be made to state, as simply as possible, the underlying theory of the cases, which appears to be as follows:

If a permit is not obtained where one is required, misrepresentation is implied as a matter of law. Insofar as the imposition of liability is concerned, this presumption is conclusive. Neither good faith, honesty, nor the exercise of reasonable care, can relieve the issuer who fails to obtain a permit from liability.

However, insofar as the period of limitation of actions is concerned, there is only a prima facie presumption of implied misrepresentation, which can be rebutted by evidence showing that the defendant had reasonable ground for believing that a permit was not required, the burden of proof being on the defendant. If the defendant proves that he honestly believed that no permit was required, and acted on information sufficient to justify a reasonable man in so concluding, this negatives or refutes any fraud, and even though the defendant was mistaken in his belief, the claim is solely for breach of warranty and the cause of action accrues at the date of sale. If, on the other hand, the defendant fails to meet such burden of proofthe presumption of implied misrepresentation thereby remaining unrebutted - the cause of action may be commenced at any time within three years after discovery of the violation.

The court did not, either in the Pickford or the Bartlett case, definitely decide whether the action for violation based solely on breach of warranty is barred within two years under Code of Civil Procedure section 339 (1) governing an action upon "a liability not founded upon an instrument of writing", or within three years under Code of Civil Procedure section 338(1) governing an action upon a liability created by statute, other than a penalty or forfeiture. This question is left for later determination. But whichever period applies, it is clear that the liability of those participating with the issuer would be governed by the same statute of limitations applicable to the issuer because their violation of the statutory duty is also the basic and real cause of action.

\section{-Criticism of rule of limitation of actions announced in the Pickford} case.

Both the Pickford and Bartlett cases involved only original parties in an issue transaction. In neither case was the court confronted with the problem of analyzing the nature of liability as extended to a sub- 
purchaser. As applied to the strict facts of the two cases, the effect of the limitations rule therein announced seems entirely unobjectionable.

But as a rule of general applicability for simple violations of the permit provisions of the Act, wholly unconnected with actual fraud in fact, it would appear that the decisions announced a hybrid rule that still leaves the problem highly confused and unsettled, for the reasons hereinafter stated. First, the theory of basic liability stated by the court seems logically unsound. It is highly and unnecessarily complicated when it could be simple and clear. Secondly, the limitation of actions rule announced by the court is extremely involved and difficult of application and, moreover, of questionable soundness in policy. These criticisms will be examined in turn. But preliminarily it is to be emphasized that in applying the statute of limitations the courts "look for reality, and the essence of the action and not its mere name." It is the basic nature of the cause of action and not the form of action chosen by the plaintiff that determines the applicability of the statute of limitations. ${ }^{41} \mathrm{It}$ is the right sought to be enforced that is the test. ${ }^{42}$

In the first place, it is believed that the supreme court failed to probe deeply enough in its analysis of the true nature of liability for violation of the Act. While the court in one breath recognizes that the liability is absolute in nature and that scienter is wholly irrelevant, in the next breath it states, in effect, that the degree of scienter or lack of scienter determines whether the liability sounds in fraud or warranty, and consequently determines the period of limitation. Since scienter is wholly immaterial to establish liability, how can the subjective state of mind of the issuer determine the nature of liability where the issuer actually told the purchaser nothing? The opinions are highly confusing because it is not clearly stated whether the variation in the element of scienter creates two wholly dissimilar types of liability-fraud on the one hand or warranty on the other-or whether there is only one basic type of liability under all circumstances, and one degree of scienter results in tolling the statute of limitations and the other does not.

Bohlen, ${ }^{43}$ Williston and other eminent writers have urged in in-

11 Cf. Miller \& Lux v. Batz (1901) 131 Cal. 402, 63 P. (2d) 680.

22 Williams v. Southern Pacific R. R. Co. (1907) 150 Cal. 624, 89 Pac. 599.

43 Bohlen, Misrepresentation as Deceit, Negligence, or Warranty (1929) 42 HaRv. L. REv. 733. 
numerable articles ${ }^{44}$ that a clear distinction must be drawn between liability for intended wrongs, liability for wrongs of negligence, and absolute diability unconnected with any fault or wrongdoing. As they have pointed out, the courts, even in cases of actual misrepresentation of fact arising under the common law and wholly unconnected with the violation of any statute, have failed properly to differentiate between cases of intentional misrepresentation and those where there is no conscious, dishonest or even negligent misrepresentation, and as a consequence have blurred and illogically distorted the concepts of deceit, negligence and warranty.

In the Pickford and Bartlett cases, the court, it is believed, has extended this confusion to a field where there is no actual misrepresentation of fact of any kind, either conscious or unconscious, and has based the liability on the dubious fiction of misrepresentation implied as a matter of law, where there seems to be no occasion whatever to resort to any such artificial theory of liability.

For the reasons fully discussed under a preceding caption, it is believed that the liability for violation of the Act is not based on fraud, or negligence, or implied warranty. It is a new type of liability created by statute. The Act makes illegal certain unlicensed action that was previously lawful. The law merely lays down the flat, inexorable fiat that if an issuer acts without a proper permit he does so at his peril-he is as absolutely liable as a person who keeps a tiger. It imposes a statutory duty which, if breached, gives rise to absolute liability, regardless of the honesty, good faith, scienter or negligence of the issuer. The duty exists only by virtue of the statute. Contrary to the statement of the court in the Pickford case to the effect that the liability depends "upon the culpability of the seller in the particular transaction", the liability is imposed regardless of the degree of culpability and, indeed, despite a total absence of culpability. The Act does not undertake "to deal with the question of abstract justice in the particular case." ${ }^{45}$ It mechanically lays down a rule of absolute rigidity. The liability attaches even though there is a complete lack of any intent or design to deceive either by misrepresentation or concealment. Moreever, it is not a tort liability for negligence, since it is imposed regardless of how high a degree of care the issuer exercises, and irrespective of the contributory negligence of the buyer. Finally, the liability is not a true extension of warranty, because the statu-

${ }^{44}$ For some of the numerous articles, see those cited in Shulman, Civit Liability and the Securities Act (1933) 43 YaIE L. J. 227.

45 Justice Cardozo, in Wendt v. Fischer (1926) 243 N. Y. 439, 444, 154 N. E. 303, 304. 
tory duty is imposed on persons who are not parties to the sale and it runs to remote purchasers, both of which notions are entirely inconsistent with the doctrine of true warranty.

In the second place, the rule of limitation of actions announced by the court is extremely difficult of application. The governing period depends entirely on the subjective state of mind of the issuer and not on any expressed word or actual representation of fact made to the buyer. Under the rule as announced, an issuer who innocently violates the Act is to a certain extent penalized more severely than the most willful defrauder, since under the rule the issuer has the burden of proving that the statute has not been tolled, whereas in cases of actual fraud plaintiff has the burden of negativing discovery more than three years before suit. ${ }^{46}$ Even though the issuer said absolutely nothing to the buyer, in order to gain the advantage of the shorter period of limitation he must prove that he had no willful intent and that he had reasonable ground for believing that no permit was required. This raises a special issue of fact. As a consequence, an issuer who is sued in various counties in the state for separate sales of securities of the same issue could fare quite differently at the hands of the respective triers of the facts. He could practically never win one case that would serve as a bar to a multitude of others. There is, of course, no rule of law to determine the fact whether a defendant had reasonable ground for believing that no permit was required. This is especially true where there is no actual representation of fact, but only a fictitious "falsity", i.e. an implied representation that a permit has been secured when one is required. The Bartlett case held that advice of counsel, given in good faith, was sufficient information to justify a reasonable man $\mathrm{m}$ concluding that no permit was required. The same rule was indicated in the Pickford case. It would also appear clear that the advice of the Commissioner of Corporations that no permit was required, although it would not relieve from liability, would be sufficient to refute the presumption of fraud and entitle the issuer to the benefit of the shorter period of limitations under the court's rule. Both cases are silent as to what other showing could be made to evidence the exercise of reasonable care.

Finally, the policy of the rule as to the limitation of actions announced in the two cases seems unnecessarily severe and unjustifiable in principle. It is to be emphasized that the ultimate test of the true limitations rule is the case where there is simply a violation of the

4616 CAL. JUR. 626-27. 
permit provisions of the Act, wholly free of any taint of actual fraud or even fraudulent concealment, either of which would evoke special treatment. The inquiry here is confined to cases where the statutory violation alone is the gravamen of the action, and where there would be no action except for such statutory violation.

Securities are fungibles which in the usual conrse of business are distributed on a wide scale and are freely traded in and pass from hand to hand. Ordinarily it requires no long period after their issuance for securities, and especially the spurious and worthless securities against which the Act is primarily aimed, to reveal their worthlessness.

It is significant that even the federal securities acts, which substantially base liability on actual misrepresentation or concealment of a material fact, and which deliberately provide in terrorem penalties and can scarcely be said to have been forged in an aura of benevolence toward sellers, fix an over-all period of three years in which suits may be brought.

The Corporate Securities Act seems sufficiently severe in imposing liability without fault, for any period. Certainly one who is subjected to absolute liability, although he has acted honestly and in good faith, should not be subjected to the harsh consequences flowing from actual fraud. To apply the three-year-after-discovery period of limitations for a violation of the Act standing alone, unless the issuer can meet the burden of proof that he did not act recklessly, as determined by the trier of the facts, seems unduly harsh. As it is, the security holder is given a "free ride" against the issuer who has violated the Act, regardless of the latter's degree of culpability. In effect, the security holder in such case has an option. He can speculate, without risk, against any such issuer who is solvent, for the full period of limitations, and can take the advantage of either a rise or fall in the market. But it would appear utterly absurd to permit a security holder to assert a violation of the Act standing alone, ten, fifteen or even twenty years after the security has been issued and outstanding, on any dubious, fictitious theory of implied misrepresentation. Such a rule would offer a temptation to use the Act itself as a vehicle for unconscionable conduct rather than as a shield against fraud.

It is to be regretted that the court, when the opportunity was presented, did not more accurately state and limit the rule as to the limitation of actions. Because of the fact that a long period may intervene before the question is again presented to the court, it would seem highly desirable that ameliorating legislation be enacted. It is 
accordingly suggested that either the Act itself or the Code of Civil Procedure should be amended to provide that any action to enforce a civil liability created by the Act must be brought within one year after discovery of the violation and in any event within three years after the bona fide issuance of the security, with a proviso that if any person has an action for actual fraud independently of the claim for violation of the Act, such separate action shall be governed by the statute of limitations with respect to fraud.

Such suggested rule would preserve the essential and salutary policy of the statute of limitations as a statute of repose, without in any wise permitting actual fraud, whenever it exists, to go "unwhipped of justice". This is aptly demonstrated by the Pickford and Bartlett cases themselves. Both of them involved the same issue of securities, although they dealt with separate sales to different buyers at about the same time. The Bartlett case involved a naked violation of the Act and consequently the claim was barred by the statute of limitations. In the Pickford case there was a finding of actual fraud in addition to the violation of the Act. The claim for violation of the Act was held barred, but recovery was permitted on the fraud charge.

Moreover, it is believed that the suggested rule would not deny relief in cases involving fraudulent concealment which fall short of actual fraud. The supreme court in Pashley v. Pacific Electric Railway Co. ${ }^{4 r}$ has clearly established the rule that when a defendant is guilty of fraudulent concealment of a cause of action the statute of limitations is deemed not to accrue until the aggrieved party discovers the existence of the cause of action, even though the underlying cause of action does not sound in fraud. In principle, there would appear to be no reason why this rule could not also be extended, in appropriate cases, to causes of action based upon liability created by statute. But obviously fraudulent concealment requires affirmative action on the part of the defendant - it should not be based on misrepresentation merely implied as a matter of law.

There is one residual problem that could arise under the rule as announced in the Pickford case that was not present in the case. Since the statutory duty of the issuer extends to subpurchasers, the question arises whether a new period of limitations would commence upon a transfer of the security by the initial purchaser to a subpurchaser. In other words, does a new period of limitations commence with each successive transfer, or is there only one period of limitations? In

47 (1944) 25 Cal. (2d) 226, 153 P. (2d) 325. 
theory it is difficult to see why any new period of limitations would commence merely on a transfer. The statutory duty is breached at the time of the original issue and it would appear that the liability would continue unbroken throughout the statutory period and would run in favor of subpurchasers, but the period would not be extended merely by reason of such a transfer. The suggested rule set forth above would make this point clear.

\section{DEALER REGULATION PROVISIONS OF THE ACT}

GENERAI

\section{Introduction.}

As previously stated, the provisions of the Act, although not formally so divided, are logically separable into two wholly different parts directed to the two main purposes of (1) security qualification, and (2) dealer-broker regulation. The latter part is comparable in a general way in its objectives with the Securities Exchange Act of 1934. The broad purpose of the dealer regulation provisions of the Corporate Securities Act is to regulate secondary market transactions, that is, resales of validly issued and already outstanding securities, in contrast to the permit provisions of the Act which relate solely to new original issues and which are loosely comparable with the Securities Act of 1933.

Dealer regulation under the Act is primarily accomplished by the requirement that dealers, brokers and agents be licensed, although certain other ancillary sanctions are provided, as hereinafter discussed.

The relatively small body of decisional law relating to the dealer provisions of the Act indicate that they constitute a minor part of it. Moreover, generally speaking, the permit provisions of the Act are a much more important complement and supplement to the Securities Act of 1933, than are the dealer regulation provisions of the Act to the Securities Exchange Act of 1934. Despite the advent of federal regulation in the securities field, the permit provisions of the Act still remain of great importance, and particularly as to issues which are exempt from the requirement of registration under the Securities Act of 1933.

On the other hand, although the dealer regulation provisions of the Act are by no means to be dismissed as unimportant, it is believed that federal regulation of dealers and brokers and secondary market transactions has more largely preempted this field, and state regu- 
lation is of far less actual concern to securities firms than federal regulation. It is believed that the dealer regulation provisions of the Act are chiefly of importance in connection with the regulation of dealer-offerings in this state of out-of-state new issues. Today, California dealers and brokers, in addition to being subject to the licensing and other powers of the Commissioner of Corporations, are subject to a variety of other sanctions. The most potent of these are, of course, the provisions of the Securities Exchange Act of 1934 and the extensive powers of the Securities and Exchange Commission thereunder. In addition, securities firms which are members of the National Association of Securities Dealers, Inc., and those which are members of the various national securities exchanges, are subject to various other restraints which are little, if any, less effective than the legal sanctions. Accordingly, it is believed that any discussion of the dealer regulation provisions of the Act alone would be fragmentary and that it is necessary to indicate their role in the entire picture and to sketch, at least in broad outline, the various other regulatory provisions to which dealers and brokers are subject.

\section{Terminology.}

\section{- In general.}

In retrospect it is almost incomprehensible how so much confusion has crept into the statutes of the various states and the judicial decisions in the use of the words "broker" and "dealer".

The Corporate Securities Act has never contained any independent definition of the term "dealer". It does not in express terms distinguish between a "broker" and a "dealer". ${ }^{48}$ However, the term "broker" is defined so as to include persons who are dealers as well as those who are brokers in the strict sense.

It is interesting to glance briefly at legislative history elsewhere in this connection. ${ }^{49}$ Practically every kind of variation in terminology exists. Like California, the securities act of Kansas, ${ }^{50}$ which was the first state to adopt a blue-sky law, defines the term "broker" so as to also include "dealer", which is itself not independently defined. This is also true of various other statutes. ${ }^{51}$ In the New York stat-

48 See Note (1931) 20 CALIF. L. REv. 84, 88; (1932) 20 ibid. 337.

49 See Corporation Manual (46th ed. 1945) in which all state blue-sky laws are set forth in full.

60 Ibid. 2428.

51 E.g., Massachusetts, ibid. 2474, and Nebraska, ibid. 2535. 
ute $^{52}$ and a number of other states ${ }^{53}$ the term "dealer" by definition even includes "issuer". In the Pennsylvania act" the term "dealer" includes the term "broker", which is not independently defined. Other states $^{55}$ define "dealer or broker" in the same comprehensive paragraph, while still other states ${ }^{56}$ define the term "dealer" and add, at the end of the definition, that the term "broker" shall mean a "dealer" as theretofore defined.

Some few states $^{57}$ which have apparently been influenced by the Securities Exchange Act of 1934, have streamlined their acts and give independent definitions both of "broker" and "dealer".

The failure properly to differentiate between brokers and dealers was even carried into the Securities Act of 1933. That act contains no independent definition of the term "broker". However, section 2 (12) of that act defines the term "dealer" to include any person who engages "as agent, broker or principal" in the business of offering, buying, selling or otherwise dealing or trading in securities issued by another person. Thus, the Securities Act of 1933 defines the term "dealer" to include "broker", in contrast to the Corporate Securitiv: Act which defines the term "broker" to include "dealer".

At about the time of the adoption of the Securities Act of 1933 there was a great deal of discussion by various publicists concerning the proper distinction between broker and dealer. Mr. Justice William O. Douglas, then Sterling Professor of Law at Yale University, and who subsequently became Chairman of the Securities and Exchange Commission, was particularly active in this respect. ${ }^{5.8}$ It may be assumed that such ventilation of the problem had some influence on the draftsmen of the Securities Exchange Act of 1934.

The Securities Exchange Act of 1934 was the first statute in which the term "broker" is clearly distinguished from the term "dealer". Section $3(a)(4)$ of that act defines a "broker" to mean any person engaged in the business of effecting transactions in securities for the

52 Ibid. 2561.

53 E.g., Maine, ibid. 2467, and Kentucky, ibid. 2441.

54 Ibid. 2644.

55 E.g., Illinois, ibid. 2374, and Michigan, ibid. 2481.

56 E.g., Indiana, ibid. 2397, and Iowa, ibid. 2415.

$5 T$ E.g., Minnesota, ibid. 2493.

58 See Bates and Douglas, Secondary Distribution of Securities-Problems Suggested by Kinney v. Glenny (1932) 41 YALE L. J. 949, and Douglas and Bates, Stock "Brokers" as Agents and Dealers (1933) 43 ibid. 46. This latter article lists the criteria and standards characterizing a dealer that were generally recognized prior to the enactment of the Securities Exchange Act of 1934. 
account of others, but does not include a bank. Section 3(a) (5) of the act states that $a$ "dealer" "means any person engaged im the business of buying and selling securities for his own account, through a broker or otherwise, but does not include a bank, or any person insofar as he buys or sells securities for his own account, either individually or in some fiduciary capacity, but not as a part of a regular business."

The characteristic distinctions between a broker and a dealer are well known. Generally speaking, a broker is a mere agent, or go-between. The legal relationship between his customer and him is that of principal and agent. This is, in reality, a relationship of status and not merely of contract, because the law itself imposes various duties on the broker regardless of the expressed intent of the parties. The most striking characteristic is that a broker is a fiduciary. The relationship is one of trust and confidence. As a consequence, a broker is held just as rigidly as a lawyer to the iron-bound duties of a fiduciary. He owes, among other duties, an undivided loyalty to his customers; he may not make a secret profit; he must treat information coming to him from the customer in the strictest confidence and must make full disclosure to the customer of all relevant information in his possession; he must make the best deal possible for the customer and properly confirm the nature of the relationship; and, in general, he must exercise the highest good faith toward his customer. If he deals adversely to his principal, or serves dual interests, full and complete disclosure must be made and an informed consent thereto obtained.

On the other hand, a dealer is not a fiduciary. He is similar to a merchant. He buys and sells as a principal for his own account and risk.

Among other distinguishing characteristics between a broker and a dealer are the following: A broker receives his compensation in the form of a commission, which is his sole interest in the transaction, and which must be disclosed. He cannot sell personally-owned securities to the customer or himself buy securities from the customer, no matter how honest his intent, because of the familiar rule of law that an agent cannot buy of, or sell to, himself. On the other hand, a dealer receives no commission. His compensation consists of the spread between the price at which he buys and that at which he sells. $\mathrm{He}$ is legally under no duty to disclose his profit in the transaction and ordinarily does not.

A sale made by a dealer is within the statute of frauds. A trans- 
action by a true broker, however, is not within the statute since there is no sale from the agent to the principal. Also, in true brokerage transactions, title passes to the customer before physical delivery of the certificate to him and the broker merely holds the securities as pledgee for the amount advanced by him. On the other hand, in the dealer-customer relationship, title ordinarily does not pass until delivery and the dealer ordinarily does not demand payment until delivery is made.

There is a further distinction with respect to transfer stamp tax liability. In the true brokerage transaction there is only one transfer or passage of title, namely, from the seller to the customer. Title does not pass to the broker and then from the broker to the customer. The dealer-customer transaction, however, gives rise to the imposition of two separate transfer stamp taxes, first, on the passage of title to the dealer, and secondly, on the passage of title from the dealer to the customer.

Section 11(e) of the Securities Exchange Act of 1934 directed the Securities and Exchange Commission to make a study of the feasibility and advisability of the complete segregation of the functions of dealer and broker. The Commission made such report on June 20, 1936, a summary of which is contained in Securities Exchange Act Release No. 739. No action, however, has ever been taken to compel a formal divorcement between these two functions. It is therefore still lawful for the same person to act both as a broker and as a dealer, subject to certain limitations.

As stated in said Report (p.xv):

"In the present status of the law, however, considerable latitude remains for the exercise of the functions of broker and dealer by the same person. Where he discloses to his customer that he is acting as dealer and obtains the customer's consent, a broker may take or supply for his own account securities named in a brokerage order. Again, he may serve a customer as broker in one transaction and as dealer in another, subject always to the requirement that the capacity in which be is acting be clearly delineated. He may also act as broker in relation to others. Moreover, he is at complete liberty to deal for his own account with persons other than his customers."

Dealers consist chiefly of investment bankers who float new issues, and "over-the-counter" houses which deal principally in securities not listed on exchanges. Many investment banking firms which are "houses of issue" also have a trading department which actively deals in unlisted securities in over-the-counter market transactions. How- 
ever, there are no clear lines of cleavage. Many large brokerage houses, although their principal business consists of brokerage transactions on the exchanges, act in addition as underwriters of new issues and also as dealers in "off-board" transactions. On occasion they act as dealers even in certain special securities listed on exchanges, because such special securities can sometimes be bought and sold more advantageously "off-board". Furthermore, the activities of houses which are only dealers are by no means limited to overthe-counter transactions in unlisted securities. In recent years private placements of listed securities by dealers has greatly expanded in importance. In such transactions the dealers purchase privately a large block of a specified listed security at the close of the exchange on one day and resell the security privately as principals, through a so-called special offering, before the opening of the exchange on the succeeding day. Indeed, this has become the accepted method of "digesting" large blocks of listed securities. Single transactions of such nature frequently run into a value of several millions of dollars.

Although the possible threat implied in the Securities Exchange Act of 1934 of requiring complete segregation of the functions of dealer and broker died aborning, there has unquestionably been a well-marked trend under federal regulation to niore and more sharply delineate the two functions. The Exchange Act itself and the rules of the Securities and Exchange Commission thereunder require a person engaged in security transactions to disclose to his customer whether he is acting as a broker for such customer, as a dealer for his own account, as a broker for some other person, or as a broker for both such customer and some other person. ${ }^{59}$

Such disclosure is ordinarily made in the confirmation. The broker's confirmation is usually "sold [or bought as the case may be] for your account and risk", or "bought [or sold] for your account." The dealer's form is usually "sold" or "sold as principal" or "sold to you" or "as principals and for our own account we have today sold to you."

Mere disclosure to the customer-especially at the conclusion of the transaction - that the investment firm is acting in a given transaction as a dealer, is not sufficient to establish a dealer relationship. For some time the Securities and Exchange Commission has been looking askance at so-called "riskless" transactions or "nonposition trading" and has thrown some doubt on their validity in a series of

59 Section 15 (c) (1) and Rule $\mathrm{X}-15 \mathrm{Cl}-4$. 
recent decisions in dealer-broker registration revocation proceedings ${ }^{60}$ that have caused nation-wide discussion. While it is not believed that these decisions purport to hold, as a matter of law, that the dealer relationship is not established if the dealer does not have the security in its inventory at the time it solicits the transaction with the customer, as a practical matter they raise a prima facie presumption of agency under such circumstances. In short, in the absence of an inventory, the securities firm is under the burden of proving that at the outset of the transaction proper disclosure was made to the customer to the effect that the transaction was to be consummated on the basis of a dealer relationship and that the customer gave his explicit consent thereto on the basis of an informed judgment. Nonaction by the customer after receiving the dealer confirmation does not constitute ratification. Subsequent ratification would require complete disclosure and explicit, affirmative and informed consent by the customer.

There is, of course, no law which forbids a securities firm from acting as a dealer, even in the absence of an inventory, provided the customer understands and explicitly consents to the dealer relationship. ${ }^{61}$ The difficult problem from the dealer's point of view is the practical question of proof, in view of the very nature of the securities business where many orders are solicited or accepted by telephone and where transactions with the same customer may be on a brokerage basis one day and on a dealer basis the next.

The facts in the previously mentioned dealer-broker registration revocation proceedings were somewhat odoriferous. The customers were unsophisticated, and some of the condemned practices clearly constituted gross fraud. Nevertheless, it must be admitted that some of the principles announced in those decisions are not limited to facts similar to those of the instant cases.

While it is the legal relationship which the parties intended to enter into that is determinative, it appears abundantly clear that the thinking of the Securities and Exchange Commission is greatly influenced, on a realistic basis, by the amount of profit or spread. There have undoubtedly been cases where unethical dealers have made unconscionable profits in transactions that are really riskless, and have

${ }^{60}$ In the matter of Oxford Company Inc. (Securities Exchange Act Release 3769, Jan. 4, 1946); In the Matter of Investment Registry of America, Inc. (Securities Exchange Act Release 3772, Jan. 11, 1946); In the matter of Norris \& Hirshberg, Inc. (Securities Exchange Act Release 3776, Jan. 24, 1946).

61 This is recognized in In the matter of Oxford Company Inc., supra note 60. 
clearly violated the rule of ethics of the National Association of Securities Dealers, Inc., which limits the amount of profit in a transaction to five per cent. But even high-grade securities firms which conduct their nonposition trading on the basis of a fair and reasonable spread-sometimes at a gross profit of only one-half pointmust clearly bring home to their customers explirit knowledge, at the outset of the transaction, that they are acting in a dealer capacity, and must obtain the customer's informed consent to such relationship. Otherwise, they may be held to the fiduciary duties of a broker, and might even expose themselves to proceedings for revocation of their dealer-broker registration by the Securities and Exchange Commission, or to suit for civil liability by their customers.

-Under the Act.

Despite some confusion in the early cases, and while it was early argued that the term "broker" under the Act had only the commonlaw meaning of one who acts as an agent for another, or as a mere "go-between", the cases have defimitely established that the term "broker" as used in the Act has a much wider meaning than the common-law definition, that the relationship of principal and agent is not essential to constitute a "broker", and that the term includes a dealer, that is, one engaged in the general business of buying and selling securities even though he acts for his own account. ${ }^{62}$

The term "broker", as used im the Act, therefore includes dealers as well as brokers in the strict sense. The term is a word of art and under the Act a "broker" is one who either (1) sells as agent for the issuer, or (2) buys or sells already outstanding securities for the account of others, or (3) buys and sells such securities as a dealer for his own account. All three functions are placed under regulation and require licensing. A "broker's" certificate issued by the Commissioner of Corporations pursuant to the Act entitles the licensee to act both as a broker and as a dealer and to perform any or all of the three functions mentioned above; its authorization is general and permits the licensee to sell, buy, and deal in securities of every description.

The term "agent" includes every person who for a compensation either (1) acts for the issuer in making sales upon original issue, or (2) acts for a broker or a dealer, or (3) acts for an mdividual

62 See, e.g., Damerel v. North American B. \& M. Co. (1933) 133 Cal. App. 290, 295, 24 P. (2d) 237, 239; Walsh v. Standard Acc. Ins. Co. (1932) 215 Cal. 587, 12 P. (2d) 16. 
selling personally-owned securities issued by another. Any person acting as agent for compensation in any of these three capacities is placed under regulation and must obtain a license. An unlicensed person could act gratuitously for an individual selling personallyowned securities of another without violating the dealer regulation provisions of the Act. Moreover, an officer of an issuer need not obtain a license in order to assist in the sale of its securities on original issue if he receives no special compensation therefor.

An agent's certificate issued by the Commissioner of Corporations pursuant to the Act is much more limited in its scope than a "broker's" certificate. It authorizes the licensee either (1) to represent an issuer in the sale of its securities on original issue, in which case his authorization is confined exclusively to the specified security, or (2) to act as agent of an individual investor in the sale of a specified security personally owned by the latter, or (3) to work for a designated "broker" (dealer), in which case he is permitted to sell any securities sold or dealt in by his employer-broker to whom he is licensed, but if he changes his employment he would have to procure a new agent's certificate.

Therefore, while all three are placed under regulation, the functions of a dealer, a broker, and an agent are each different. These terms are used hereafter $\dot{m}$ a strict sense, except when the word broker is placed within quotation marks, when it means either a dealer or broker or both.

\section{SCOPE OF REGULATION}

\section{General.}

The dealer regulation provisions of the Act are concerned only with resales and not with the original issue of securities, except only for the requirement of the licensing of a broker or an agent who is employed by an issuer for the specific purpose of making sales of securities upon an original issue. This portion of the Act does not apply to original issues nor to the necessity of obtaining a permit. As discussed under a previous caption, it is believed that neither dealers, brokers nor agents who are not acting for the issuer are under the statutory duty of ascertaining that a permit has been obtamed. Of course, neither a broker nor an agent acting for an issuer, or possibly even an underwriter, can, with knowledge of a lack of a permit, legally sell securities for which no permit has been obtained if one is required. The law unquestionably puts the burden on any 
such seller of securities to see that they can be lawfully sold. Moreover, an agent or broker acting for the issuer-and possibly also an underwriter-is a person actively participating in the original issue of such securities and would be violating the permit provisions of the Act if sucn securities were issued without a permit or in nonconformity with the terms of a permit.

As heretofore stated, the entire field of resales of securities has been placed under regulation with the sole exception that, by reason of the decision in the case of People v. Pace, ${ }^{63}$ a bona fide individual owner of securities issued by another may, without obtaining a broker's license, sell such personally-owned securities (a) directly for his own account, if he does not engage either wholly or in part in the business of dealing in securities, or (b) through an unlicensed agent, provided such agent receives no compensation therefor. If the agent is to receive a commission or any compensation, he would have to be licensed as an agent for such individual under the Act, and if such individual owner engages in whole or in part in the business of selling securities, he inust obtain a "broker's" license before so doing. Subject to these two limited exceptions, the entire field of resales of securities is placed under regulation and no person can act either as a dealer, broker or agent without obtaining a license from the Coinmissioner and complying with the other applicable dealer regulation provisions of the Act.

\section{Isolated transactions.}

The general rule is that a person engaged in other business who acts as a broker on a single occasion but not as a regular business, is not precluded from recovering compensation by reason of failing to have procured a broker's license pursuant to a statute requiring those engaged in the business of a broker to obtain a license. ${ }^{64}$ In contrast, the California Real Estate Law (section 10134) expressly requires a broker's license even for a single, isolated transaction, and the cases have held that there can be no recovery where there has been violation in a single transaction and, moreover, that subsequent compliance with the statute will not cure the illegality of the previous contract. ${ }^{65}$

63 (1925) 73 Cal. App. 548, 238 Pac. 1089.

64 Notes (1926) 42 A.I. R. 1230; (1939) 118 A.L. R. 657.

65 Haas v. Greenwald (1925) 196 Cal. 236, 237 Pac. 38; Wise v. Radis (1925) 74 Cal. App. 765, 242 Pac. 90. 
The Corporate Securities Act is not as explicit and does not in express language require a broker's license for a single transaction. A broker, under the Act, is one who engages either wholly or in part in the business of selling, etc. On its face this language would not make a single, isolated transaction by an unlicensed person illegal. However, in the comparatively early case of Van Wyke v. Burrows ${ }^{\text {bs }}$ it was held that the conduct of an unlicensed person acting as an agent in a private transaction in which but a single sale was involved, constituted a violation of the Act. This case is of highly doubtful authority since it was clearly based on a misreading of the Act. Subsequent cases, although not purporting to overrule Van Wyke v. Burrows, have permitted recovery of compensation in cases involving a single sale by a person not licensed as a stock broker, either on the theory that such person was not a true "broker" under the Act, ${ }^{67}$ or on the theory that the contract was capable of performance in a legal manner other than on a brokerage basis. ${ }^{68}$ Nevertheless, it is believed that the only safe course for a person participating as a broker in a sale of stock who expects to receive compensation for his services, is to obtain a broker's certificate, even though he is not regularly engaged in business as a stock broker, and even though only a single transaction is involved. Owing to tax and other reasons, it is sometimes impossible to forecast how a given sales transaction will finally emerge, whether as a sale of corporate assets or merely as a sale of the entire outstanding shares of the corporation. Such transactions are sometimes negotiated by licensed real estate brokers and sometimes by hicensed stock brokers. In every case where there is any doubt, the safe course is for a real estate broker also to obtain a stock broker's license from the Division of Corporations and, conversely, for the licensed stock broker to obtain from the Real Estate Commissioner both a real estate broker's license and a business opportunity license under chapter 4 of the Real Estate Law.

\section{Transactions in exempted securities.}

There was formerly some doubt as to whether a person acting as a dealer, broker or agent exclusively in the sale of securities expressly exempted under the Act was required to be licensed. In the abovementioned case of Van Wyke v. Burrows, which was clearly based

66 (1929) 98 Cal. App. 415, 277 Pac. 190.

67 McKenna v. Edwards (1937) 19 Cal. App. (2d) 327, 65 P. (2d) 810.

68 Gardiner v. Burket (1935) 3 Cal. App. (2d) 666, 40 P. (2d) 279; Dougherty v. Cross (1944) 65 Cal. App. (2d) 687, 151 P. (2d) 654. 
on a misreading of the Act as then in effect, the district court of appeal held that an unlicensed broker selling in a private transaction an exempt security (bank stock), even though but a single sale was involved, was subject to the terms of the Act and consequently could not recover an agreed commission on the ground that the contract for the commission was illegal since he had failed to procure a license as required by the Act. Despite this decision, the Attorney General subsequently delivered opinions to the Commissioner of Corporations to the effect that a "broker" dealing exclusively in securities expressly exempted under the Act was not required to be licensed under the Act. ${ }^{69}$ On principle, this would clearly appear to have been the law prior to the 1933 amendment to the Act. Up to that time section 2(b) of the Act provided as follows:

"(b) Except as hereinafter otherwise expressly provided, the provisions of this act shall not apply to any of the following classes of securities: ...."

Immediately following this language was a list of eleven classes of exempted securities. No subsequent provision of the Act expressly limited exemptions with respect to any requirement of licensed brokers. It would therefore appear doubtful whether dealers, brokers or agents who dealt exclusively in exempted securities were subject to regulation under the Act prior to the 1933 amendment. This doubt was finally removed in 1933 when section 2(a) (10) of the Act was amended and the word "broker" was defined to mean every person other than an agent who engages in the business of selling or dealing in any security issued by others, including expressly all exempted securities except only (1) memberships in nonprofit companies or associations, (2) bills of exchange, trade acceptances, promissory notes, and other commercial paper issued, given or acquired in a bona fide way in the ordinary course of business, trade or commerce, and (3) promissory notes, whether secured or unsecured, if said notes are not offered to the public or are not sold to an underwriter for the purpose of resale. Accordingly, even a dealer or broker who engages exclusively in buying and selling government or municipal bonds is placed under regulation and must be licensed, and otherwise comply with the dealer regulation provisions of the Act.

While under the doctrine of the Pace case the state cannot regulate sales by a bona fide individual owner of personally-owned securi-

69 In one of such opinions rendered October 31, 1931, the Attorney General expressly referred to the Van Wyke case, supra note 66 , but considered it not controlling. 
ties for his own account if he does not engage in the business of dealing in securities, it clearly can regulate under the police power the business of dealing in securities even though they fall within the classifications of securities expressly exempted from the permit provisions of the Act. ${ }^{70}$

Purchases of securities in California by unlicensed foreign dealers.

There is an ambiguity in the wording of the amendment to section 2(a) (10) which was adopted in 1933 which has given rise to some doubt as to whether an out-of-state underwriter or dealer, unlicensed in California, can purchase in California securities exempted under the Act even though such an underwriter or dealer does not intend to reoffer or resell such securities in California. This ambiguity arises out of the language defining a "broker" as "every person or company other than an agent, who shall, in this State, engage either wholly or in part in the business of selling, . . . any security issued by others . . . or of underwriting any issue of such securities or of purchasing such securities with the purpose of reselling them, or of offering them for sale to the public." On a strict reading, this language is susceptible of the construction that a New York underwriter or dealer, whose business is confined exclusively to the State of New York and who is not licensed as a "broker" (dealer) in California, could not purchase in California exempt securities, e.g., public utility bonds authorized to be sold by the Railroad Commission of the State of California, even though he did not intend to offer the bonds so purchased by him in California, since the last two clauses of paragraph (10) do not limit in express terms resales or offers to the public in California. The words "in this State" are contained in the second line of paragraph (10), but doubt has been expressed as to whether this clause qualifies and modifies all of the language following it in the paragraph. It is believed that it clearly was intended to do so, and that such foreign underwriters or dealers are excluded from the definition of the paragraph. Such has been the consistent, continuous, practical construction of the Act by the Commissioner of Corporations. Under the familiar rule that a contenuporaneous, consistent, practical construction of an ambignous statute by the officer charged with the duty of its administration will be respected by the courts, it is believed that the courts will adopt the administrative construction. Indeed, it is doubtful whether any other construction would be

70 People v. Woolsey (1936) 13 Cal. App. (2d) 54, 56 P. (2d) 557. 
constitutional. Thus, an out-of-state underwriter or dealer could, without being licensed, legally underwrite or purchase in California the whole or a portion of an issue of securities exempt under the provisions of the Act if he resells them or offers them for sale exclusively outside of California.

\section{METHOD OF REGULATION}

\section{General.}

The Act itself has never required "security qualification" of any securities resold by dealers, brokers or agents. For a relatively short period, commencing August 1, 1930, the Commissioner of Corporations, purporting to act under his "rule-making" power, but without any express statutory authorization empowering him so to do, attempted to require "stock brokers" selling or dealing in securities, even though personally owned, to have such securities "approved for trading" by the Commissioner. The only reference found in the Act itself to an "approval for trading" is in the 1931 amendment to section 26 of the Act prescribing fees, paragraph 10 of which provided as follows:

"10. For filing any request for an approval for trading any security, $\$ 25.00$.

However, this provision was dropped in the 1933 amendment to the Act and has not since been found in the Act. The first rule on the subject was Rule 26, effective August 1, 1930, setting forth "Requirements governing brokers dealing in listed and unlisted securities." Section 1(a) of that Rule provided as follows:

"No stock broker will be permitted to trade or to deal in any unlisted security of a foreign corporation regardless of whether such security is personally owned or not, or to trade in any security listed or admitted to trading on any stock or curb exchange, unless and until there shall have been submitted to the Commissioner such data as will enable him to determine whether the sale of such security will not be unfair, unjust or inequitable to the purcliaser thereof and such security approved for trading by the Commissioner; with the exception that stock brokers will be permitted to trade and to deal in sucls security between themselves, but this exception shall not be construed as permitting trading or dealing in such securities witl investors other than stock brokers."

Paragraphs (b), (c), (d), (e) and (f) of section 1 of the Rule provided, in general, that approval for trading could be made by the Commissioner on his own motion, that securities listed on recognized 
national security exchanges were automatically approved for trading, that securities of a company the report of whose financial status could be found in any standard published manual such as Walker's, Poor's, Moody's or Standard Statistics, would be approved or disapproved for trading on the basis of such report as the facts would warrant, and that securities exempt under the permit provisions of the Act were automatically approved for trading. Paragraph (g) provided for the approval of any remaining securities upon application.

Of course, any security approved for trading, whether automatically, or on the Commissioner's own motion, or on application, no matter by whoin the application was filed, was approved as to all "stock brokers".

Rule 26 was superseded by Rule 23, effective August 1, 1931, which was substantially the same as the prior Rule except that it excluded unlisted securities of a foreign corporation as to which a permit of the Commissioner had been granted, and dropped the language "regardless of whether such securities are personally owned or not", thereby excluding dealers from the operation of the rule.

However, the practice of the Commissioner in requiring such approvals for trading was discontinued in the Fall of 1931 and has never been revived.

There has always been serious doubt entertained as to whether either Rule 26, or even subsequent Rule 23, which had a much narrower scope and applied only to true brokers and not to dealers, was valid. It could be strongly urged that these rules went far beyond the Commissioner's "rule-making" power and amounted to an attempt by him to legislate and were therefore void and of no force as a usurpation of power. At most, they were regarded by the Division of Corporations itself as in the nature of extensions of the other powers of the Commissioner, such as the power over advertising, stop-order power to prevent unfair sales, etc.

Aside from this brief attempt solely by rule of the Commissioner, there has never been any requirement that a dealer, broker or agent must "qualify" the security itself. As previously pointed out, the Corporate Securities Act differs radically in this respect from the blue-sky laws of several other states which require registration or qualification of any security sold by an issuer, dealer, broker or other person.

Specific sanctions.

Regulation of the whole field of resales of securities is sought 
solely by regulation of dealers, brokers and agents. This regulation is effected by the requirement that dealers, brokers and agents be licensed, that dealers, brokers and agents file all advertisements and circulars with the Commissioner, by giving the Commissioner a stoporder power over dealings by "brokers", by the power of injunction lodged in the Commissioner, and by various other sanctions directed against dealers, brokers and agents.

Thus, the Commissioner is armed with a whole arsenal of sanctions to enforce the Act. These sanctions are extremely effective in the policing of the entire field of resales of securities. They are, however, immaterial in determining questions of civil liability for violation of the dealer regulation provisions of the Act.

\section{-Licensing provisions-granting or denying and suspending or revoking of license.}

No person can act as a dealer, broker or agent unless licensed by the Commissioner. The "broker's certificate" and "agent's certificate" are issued upon verified application made to the Commissioner, after investigation by him, if he is satisfied that the applicant is of good business repute and financially responsible, intends to make sales in a inanner and method that would not be unfair, unjust or inequitable to purchasers, has not violated any of the provisions of the Act, and has not engaged or is not about to engage in any fraudulent transaction. ${ }^{i 1}$ Both the broker's certificate and agent's certificate expire on the 31st day of December next after its issuance unless sooner suspended or revoked, or unless the holder of such certificate shall file an application for renewal thereof and pay the annual license fee for the next succeeding calendar year on or before the fifteenth day of December prior to the expiration of such certificate. As heretofore noted, the "broker's certificate" entitles the licensee to act both as a dealer and as a broker, and confers a general authorization to deal in securities of every description. The "agent's certificate" limits the agent either to act for an issuer of a particular security or to act for a designated "broker" or an individual investor.

The granting of a license by an administrative officer is an exercise of delegated legislative power. ${ }^{72}$ The Commissioner of Corporations does not exercise any true judicial function. ${ }^{73}$ "Our courts have

71 Section 7.

i2 Porter v. Investors Syndicate (1932) 286 U. S. 461.

73 Schwab-Wilson M. Corp. v. Daugherty (1936) 15 Cal. App. (2d) 701, 59 P. (2d) 1057; Blue v. Division of Corporations (1935) 8 Cal. App. (2d) 485, 48 P. (2d) 80. 
determined that the Commissioner of Corporations is authorized to exercise discretionary administrative functions but is without authority to exercise judicial functions." ${ }^{24}$ Since the Commissioner clearly does not exercise judicial functions, certiorari to review any order of his denying an application for a license is not available. ${ }^{\text {is }}$ In the exercise of his administrative functions he has a wide discretionary power to grant or deny the application. Thus, he may deny the application on the basis of his finding that applicant is of "bad business repute", and his finding of fact, based upon evidence, is conclusive on a court of review. ${ }^{76}$

In the case of an administrative proceeding which is adjudicatory in its nature, due process requires notice, a full and fair hearing, and a method of securing relevant and material evidence. However, in an administrative proceeding which is purely legislative in nature, due process does not require notice or a full and proper hearing. The administrative proceeding conducted by the Commissioner to determine whether he will grant or deny the application for a license is not judicial in nature and accordingly due process does not require notice or a full and proper hearing. "The "investigation" that the Commissioner conducts to determine whether he will grant or deny the application is not a true "hearing". is

It is to be noted that the authorities usually draw a clear distinction between (1) the granting or denying of a license and (2) the suspension or revocation of a license already granted. ${ }^{70}$ The former type of proceeding does not require notice and a full hearing but the latter ordinarily does, since, in the language of the cases, they involve the deprivation of a vested right. ${ }^{80}$

It is also to be noted that the only remedy of a person who is denied a license or whose license is suspended or revoked is by writ of nuandamus to compel the administrative officer to grant the license

74 Dysart v. Daugherty (1936) 17 Cal. App. (2d) 525, 62 P. (2d) 612.

75 Cf. Standard Oil Co. v. State Board of Equal. (1936) 6 Cal. (2d) 557, 59 P. (2d) 119; Whitten v. California State Board, Etc. (1937) 8 Cal. (2d) 444, 65 P. (2d) 1296.

To Leach v. Daugherty (1925) 73 Cal. App. 83, 238 Pac. 160.

77 Ibid.; McDonougl v. Goodcell (1939) 13 Cal. (2d) 741, 91 P. (2d) 1035.

78 Cf. In re Securities and Exchange Commission (C. C. A. 2d, 1936) 84 F. (2d) 316, distinguishing between a "hearing" and an "investigation".

79 Hankins, The Necessity for Administrative Notice and Hearing (1940) 25 Iowd L. REv. 457,469 .

80 Suckow v. Alderson (1920) 182 Cal. 247, 187 Pac. 965 ; cf. Abrams v. Daugherty (1922) 60 Cal. App. 297, 212 Pac. 942. 
or to compel the Commissioner to set aside his order of suspension or revocation. The decisional law has been clear to the effect that the scope of review in a mandamus proceeding differs greatly in a case where the license has been denied from that in which an existing license is suspended or revoked. ${ }^{81}$ On a review of a refusal to grant a license, the court feels itself bound to accept the findings of the Commissioner if supported by substantial evidence, and will not interfere with the exercise of his discretion except in the case of an abuse thereof, which can only be established by showing that he acted arbitrarily, capriciously, or fraudulently. ${ }^{82}$ On the other hand, under the present rule as established by the decisions of the California supreme court, on a review of an order suspending or revoking a license, the reviewing court must exercise an independent judgment on the facts and receive material evidence, and indeed, to a limited extent, try the case de novo. ${ }^{83}$

The Commissioner of Corporations is now subject in his licensing and disciplining powers to the provisions of the new Administrative Procedure Act adopted in $1945 .{ }^{84}$ Section 11504 of that act expressly

81 Cf. (1939) 27 CaIIF. L. Rev. 738.

$82 \mathrm{McDonough}$ v. Goodcell, supra note 7 .

83 Drummey v. State Bd. of Funeral Directors (1939) 13 Cal. (2d) 75, 87 P. (2d) 848; Laisne v. Cal. St. Bd. of Optometry (1942) 19 Cal. (2d) 831, 123 P. (2d) 457. The majority opinion in the Laisne case holds that because of the restrictive judiciary provisions of the state constitution which forbid judicial power being vested in a statewide administrative agency, binding fact-finding power cannot constitutionally be conferred upon such an agency, and that a reviewing court must exercise an independent judgment on the facts as well as on the law. This is in sharp contrast with the wellestablished federal rule which makes administrative findings of fact conclusive if supported by substantial evidence. A vigorous dissent by three justices in the Laisne case contends that the adjudicative powers of a state-wide agency are merely "quasijudicial" and its determinations of fact are final if supported by substantial evidence. Mandamus is the only means by which the revocation of a hicense by a state-wide agency may be judicially reviewed. In contrast, adjudicatory determinations of local agencies are reviewable either by certiorari or mandamus, and their findings of fact are conclusive if based on substantial evidence. Walker v. City of San Gabriel (1942) 20 Cal. (2d) 879,129 P. (2d) 349. In subsequent cases, the court has limited and qualified the concept of a trial de novo on a review of the action of a state-wide administrative board. Dare v. Bd. of Medical Examiners (1943) 21 Cal. (2d) 790, 136 P. (2d) 304; Russell v. Miller (1943) 21 Cal. (2d) 817, 136 P. (2d) 318. Also, the Legislature at its 1945 session added section 1094.5 to the Code of Civil Procedure, relating to the judicial review of administrative determinations. Cal. Stats. 1945, p. 1636.

84 Cal. Stats. 1945, p. 1626, CaL. Govt. CoDe $\$ 11500$ et seq. This act does not purport to be a complete code of administrative law and procedure. It merely covers formal, adjudicatory proceedings of certain enumerated state licensing and disciplining agencies. See Kleps, California's Approach to the Improvenent of Administrative Procedure (1944) 32 CaLIF. L. Rev. 416. 
provides that "proceedings to determine whether a license should be issued or renewed shall be governed by the provisions of this chapter...." Accordingly, the distinction between "investigation" relating to the granting or denying of a license, and "hearings" on suspensions or revocations, heretofore so sharply drawn in the decisional law, is now abrogated, and an applicant whose application is denied is entitled to a hearing and to judicial review.

In addition to the broad discretion conferred on the Commissioner to grant or deny licenses to dealers, brokers and agents, he is given power to suspend or revoke any broker's or agent's certificate for cause after a hearing upon notice (section 7). As previously stated, due process requires such notice and a full hearing before there can be a suspension or revocation. Even though the brolser attempts to surrender his certificate after service of notice by the Commissioner to show cause why it should not be suspended or revoked, the Commissioner may nevertheless proceed with the hearing after the attempted surrender of the license, especially if made before the commencement of the hearing. ${ }^{85}$ However, the Commissioner of Corporations for at least ten years has distinguished between an attempted surrender of an existing license and a withdrawal by an applicant of an application for a license filed by him. The Commissioner has consistently, since the decision of Milton L. Kane, Petitioner, v. F. G. Athearn, Commissioner of Corporations of the State of California, ${ }^{80}$ taken the position that he has no power to refuse an applicant's request to withdraw an application. Nevertheless, the Commissioner asserts the power to proceed with his investigation and malke findings and, in appropriate cases, enter a cease and desist order even though the applicant has withdrawn his application.

By way of comparison, it is of interest to note briefly the scheme of licensing under the Securities Exchange Act of 19.34. Under that act licensing is effected by registration under rules and regulations of the Securities and Exchange Commission. ${ }^{87}$ The Commission is also empowered to suspend or revoke the registration of any dealer-broker, for cause, after appropriate notice and opportunity for hearing. ${ }^{88}$

85 Daugherty v. Superior Court (1937) 23 Cal. App. (2d) 739, 74 P. (2d) 549.

86 (August, 1930.) This is an unreported case of the Superior Court of the State of California in and for the City and County of San Francisco (No. 218526), wherein Judge Walter Perry Johnson vacated and set aside an order of the Commissioner denying an application for a broker's license after the applicant had witbdrawn his application.

87 Section $15(\mathrm{~b})$.

88 Section $15(\mathrm{~b})$. See revocation proceedings cited supra note 60 as illustrative of the procedure. 
-Stop-orders, injunction, advertisements, etc.

Since 1925 (when the power was first added in old section 9 of the Act) the Commissioner has had a "stop-order" power and can order any "broker" to cease and desist from selling any security after notice given to him by the Commissioner that, in the latter's opinion, the sale thereof or the manner or method of sale thereof would be or is unfair, unjust or inequitable to the purchaser (section 13). Such control over the "mamier or method of sale" of a security was first added by the amendment to section 13 which became effective August 14, 1931.

Since 1931 the Commissioner has also been authorized to bring an action for an mjunction whenever he believes, from evidence satisfactory to him, that any person has violated or is about to violate any of the provisions of the Act (section 19).

Since the inception of the Act the Commissioner has had broad powers over all advertisements, circulars, etc., concerning any security offered for sale (section 10). Such advertisements or circulars must carry the name of the broker, agent or person circularizing the same, and a true copy must first be filed in the office of the Commissioner at least one day prior to the circularization or publication. If such copy is so filed, there is no further duty on the "broker" or "agent" unless the Commissioner himself takes affirmative action and requests further information froin the "broker" or "agent" or directs some further order to him. Under California practice it is not deemed illegal if any advertisement carries, in addition to the names of licensed dealers, the names of unlicensed out-of-state dealers so long as the latter do not actually make any sales in California.

Also, at all times since the inception of the Act "brokers" have been required to file with the Commissioner such reports concerning their business "as the Commissioner niay require" (section 12).

As explained under a previous caption, no permit is required where securities of a foreign issuer are delivered outside of the state and then imported here for the purpose of resale by dealers licensed in this state. As a consequence, the Commissioner of Corporations has no power to mold and fix the terms of such securities at the time of original issue. However, even though his powers of control over such securities by means of the dealer regulation provisions of the Act are not as plenary as his powers over securities for which a permit must be obtained, they nevertheless can be made highly effective.

Dealers who do not scrupulously comply with section 10 of the 
Act, which requires the Commissioner's approval of all advertisements, prospectuses, offering sheets, etc., expose themselves to "stoporder" proceedings, to possible proceedings for the suspension or revocation of their "broker's" licenses, and even to possible criminal prosecutions. The reputable securities firms are extremely meticulous in this regard. Moreover, the Division of Corporations insists on strict compliance with the provisions of section 10 since action thereunder constitutes its primary control over out-of-state issues. Upon such filing under section 10 of the Act the Commissioner is able to analyze the soundness of the issue, the fairness of the price, and the spread or profit to the dealer.

Even in cases where the investor is openly advised that the security is highly speculative, the Commissioner, if he considers that the security is unsound or that the price has no fair relation to value, or that the spread is unconscionable, frequently forbids the sale of such securities by dealers in this state, regardless of nonaction by the regulatory bodies of other states.

Of course, any sale of a security in any manner by an unlicensed agent or "broker" violates the Act. But it is to be einphasized that after a "broker" has duly obtained his certificate, and complied with the applicable provisions of section 10 of the Act by seasonably filing any advertisement, circular, etc., concerning any security being sold by him as to which he uses any advertisement or circular, he is free to engage in selling and dealing in all securities being dealt in by him. All of the above-mentioned sanctions require affirmative action by the Commissioner and some additional request or demand by him before such licensed broker will be deemed to have violated any of the dealer regulation provisions of the Act. He must, upon the request of the Commissioner, furnish the latter such additional information concerning any security being offered for sale as the Commissioner shall request, or he must cease and desist from selling such security if the Commissioner determines that the sale thereof or the manner or method of sale thereof is unfair. However, if a licensed "broker", to the knowledge of the Commissioner, is engaged in selling or dealing in any security, provided only that he has complied with the applicable provisions of section 10 relating to advertisements and circulars, such "broker" is not guilty of any violation of the Act unless the Commissioner objects to such selling by the "broker" and the "broker" after notice of such objection fails to comply with such affirmative request or order of the Commissioner. 


\section{-Criminal penalties.}

The criminal penalties of section 18 apply to violations of the dealer regulation provisions of the Act as well as to violations of the permit provisions of the Act.

\section{CIVII IIABIIITY}

\section{Statutory bond.}

Except only for the statutory provision requiring a "broker" to file and maintain a bond in the penal sum of five thousand dollars, the Act is wholly silent as to civil liability for violation of any of the dealer regulation provisions of the Act.

The requirement of a "broker's" bond was first added in 1923 and is presently contained in section 6 of the Act, which requires that at the time of filing an application for a "broker's" certificate the applicant shall file and thereafter maintain with the Commissioner a good and sufficient bond in the aggregate penal sum of $\$ 5,000$, payable to the people of the State of California, for the use and benefit of interested persons, executed by the applicant and by a sufficient surety or sureties, and to be approved by the Commissioner. The total aggregate liability on such bond is limited to the payment of $\$ 5,000$ regardless of the number or amount of claims that may be asserted against it. The liability of both the principal and surety under the bond is, of course, clearly contractual ${ }^{39}$ Prior to the 1925 amendment to the Act, such "broker's" bond did not cover cases of breach of contract, conversion or misappropriation, ${ }^{90}$ but was limited to cases where the "broker" was guilty of fraud. By the 1925 amendment to the Act the liability under the bond is extended to cover any case of damage by reason of any violation of the Act, and it even covers conversion by repledging for an indefinite sum..$^{91}$ The liability is not limited to losses arising through sales of securities subject to the control of the Commissioner of Corporations. ${ }^{92}$ However, the bond does not cover acts of a broker's agent clearly outside the scope of his employment, ${ }^{93}$ nor does it cover certain transactions between brokers themselves not involving the public. ${ }^{94}$ In 1933 the section was amended to include a two-year limitation on actions brought on a broker's bond.

80 Betzer v. Olney (1936) 14 Cal. App. (2d) 53, 57 P. (2d) 1376.

90 Kennepohl v. Cary \& Co. (1931) 112 Cal. App. 413, 296 Pac. 897.

91 Fiedler v. Allen (1931) 117 Cal. App. 622, 4 P. (2d) 292.

92 White v. Financial Guarantee Corp. (1936) 13 Cal. App. (2d) 93, 56 P. (2d) 550;

McDevitt v. Butte City Ranch (1935) 7 Cal. App. (2d) 252, 46 P. (2d) 290.

93 Sharp v. E. D. Leavitt \& Co. (1931) 111 Cal. App. 634, 295 Pac. 1082.

24 Roberts, Thomas \& Co. v. Allen (1932) 215 Cal. 595, 12 P. (2d) 451. 


\section{General.}

Aside from cases on "brokers" bonds there have been surprisingly few decisions involving civil liability for violation. As previously stated, the Act is completely silent as to questions of civil liability except with respect to the broker's bond. Moreover, it is to be observed that the voiding section, which in the case of an original issue in violation of the permit provisions of the Act makes the security itself void, has no application whatever to violations of the dealer regulation provisions. The only ground for civil liability is founded on the principle that any contract in violation of a penal statute is illegal. The applicable rule was established in the leading case of Smith v. Bach ${ }^{95}$ which, while not involving the Corporate Securities Act, establishes the law in California for violations of a penal statute. Under the rule of that case, where money has been paid in consideration of an executory contract which is illegal, the party who has paid it may repudiate the agreement at any time before it is executed and reclain the money, even though he had knowledge of the illegality.

Moreover, it would appear clear that wherever there has been a resale of securities in violation of the dealer regulation provisions of the Act, such sale, whether executory or executed, is illegal. However, since the security itself is not void, any liability of the seller would clearly extend only to his immediate purchaser and not to subpurchasers.

\section{Remedies and Defenses.}

Except for cases involving "brokers" bonds, no case has been found where a buyer was seeking affirmative relief against the seller inerely on the grounds of violation of the dealer regulation provisions of the Act. There have been several cases in which an unlicensed seller has sought to recover commissions or compensation and has been denied recovery on the grounds that the contract is illegal. ${ }^{90}$

It is therefore not clear what affirmative relief a buyer is entitled to if he purchases securities from a seller who violates the dealer regulation provisions of the Act where there is a total absence of misrepresentation of value or other actual fraud. In such case the seller is neither liable for fraud nor for breach of warranty. Such seller, whether a dealer or broker or agent, is not guilty of breaching the

95 (1920) 183 Cal. 259, 191 Pac. 14.

${ }^{96}$ Brandenburg v. Miley Petroleum Exploration Co. (N. D. Cal. 1926) 16 F. (2d) 933; Van Wyke v. Burrows, supra note 66. 
implied warranty of validity mentioned in the Pickford case, since the security itself is clearly valid and title passes to the buyer. The violation is merely a violation of the penal statute which renders the contract illegal. On principle, it would appear clear that the buyer seeking affirmative relief in such case would, aside from action on the broker's bond, be limited to the remedy of rescission. Since the security itself is not invalid, privity would be required and relief would be limited to the initial buyer from the seller who violated the Act. Moreover, it would appear clear that the plaintiff would have to make full restoration. If prior to discovery of the violation he had disposed of the security, he would have to tender equivalent securities. If, on the other hand, the contract were still executory and such buyer had received nothing, he could repudiate the contract at any time before it was executed and reclaim the money under the rule of Smith $v$. Bach.

Of course, such buyer would be entitled to assert the illegality defensively and the seller could not recover on any executory contract. Although the liability of the seller in such cases would seem to be grounded on the doctrine of Smith v. Bach, it is not clear whether the governing statute of limitations would be the same as that applied in that case, which held that the applicable statute of limitations was Code of Civil Procedure section 339(1), viz., two years after the sale, or the three-year statute prescribed by section 338(1) of the Code of Civil Procedure governing an action upon a liability created by statute, other than a penalty or forfeiture. In any event, it would appear clear that the three-year-after-discovery statute, prescribed by section 338(4) would not be applicable.

\section{CONCLUSION}

Inherent limitations of securities regulation generally.

Securities in one form or another constitute the bulk of all wealth in our modern industrial economy. State regulation, of some kind, of primary and secondary distributions of securities is unquestionably an imperative. There can be no doubt that securities transactions should be controlled-the only question is the extent to which they should be regulated.

The problem of the limits of state control over securities is merely one facet-but an extremely important one- of our greatest contemporary domestic problem, namely, the limits of state action generally. It poses very sharply the conflict between statism and individualism. In the totally collectivist state there is of course no problem of securi- 
ties regulation. There simply are no securities, because the state has literally devoured them.

In states that still recognize free enterprise there is a wide divergence in the views of even those who profess to believe in the institution of private property as to the proper scope of state controls over securities transactions. The protagonists of extremely paternalistic securities acts believe that the weak and the ignorant can be effectively protected by state action against their own speculative follies. They advocate that the state should actually pass on the soundness and quality of all security issues. They are apparently sincerely convinced that through state controls we can somehow achieve securities that are truly "secure". This of course implies, at least to some extent, an evaluation and a selection of securities by public authorities.

The opponents of this theory believe that it is unrealistic and fallacious for several reasons. Their argument, in the main, runs briefly as follows. First, in the inherent nature of things, men cannot be protected from their own speculative folly. Secondly, the state is not endowed with any such omniscience or clairvoyance as enables it to select, or to pass upon the soundness or quality of securities, or prognosticate their future value. Finally, in this uncertain world, there is really no such thing as a "secure" security.

In the nature of things, government cannot effectively control the soundness of securities. It is inconceivable that the state should set up a super board or commission that would evaluate securities and dispense investment advice to its citizens. The very complexity of the securities market makes the bare suggestion absurd. Every governmental agency in the nation that exercises any regulation over securities has an abhorrence of any suggestion that it "recommends" or "approves" any security subject to its jurisdiction. Every federal or state securities act is negative in essence. Regulation can really do no more than screen off the spurious and the worthless. It is incapable of any degree of affirmative selectivity. The state cannot police the affairs of all the investors of the nation. In the quaint words of Adam Smith:

"The statesman who should attempt to direct private people in what manner they ought to employ their capitals, would not only load himself with a most unnecessary attention, but assume an authority which could safely be trusted to no council and senate whatever, and which would nowhere be so dangerous as in the hands of a man who had folly and presumption enough to fancy himself fit to exercise it." 
What are the inherent limits of state control over securities transactions?

Even the most passionate individualist would not deny that the prevention of fraud and the exploitation of ignorance is an essential and proper function of the state. That is the minimal ideal in the field of securities regulation. It is believed that the maximum attainable ideal is equality of knowledge of all the material facts concerning securities. But the state cannot confer equal judgment or vision by a general franchise any more than it can control the wheel of chance or abolish all risk. Every economic venture involves riskand some luck-and even in those risks worth taking only a few can win.

There is no law or ethic that condemns a director who purchases securities of his corporation from a fellow director. Both have equal means of knowledge of the facts, but their respective prognostications of the future may be sharply divergent. On the other hand, it is legally just as wrong as it is morally reprehensible, for any officer or director of a corporation, or other "insider", to profit by his superior knowledge of the facts by exploiting the ignorance of minority stockholders in purchasing their shares from them.

No one could rationally or ethically quarrel with the theory of "truth in securities". But only visionaries can believe that the state can extend regulation to the point where buyers would receive only "sound" securities. If full and accurate disclosure can be achieved, if fraud and the exploitation of ignorance can be eliminated, if bald dishonesty and unconscionable greed can be ruled out, we will have well-nigh reached the limits of effective state action.

It is difficult to see how state regulation in the field of securities transactions, except for special situations, including public utilities and so-called moneyed corporations such as banks and insurance companies, can effectively extend beyond the full and accurate disclosure theory and the prevention of fraud. Fundamentally, the paramount purpose of state securities acts is the one implied by their popular label, that is, to prevent unscrupulous exploiters from selling the "blue sky". State control can negatively screen off securities that are obviously worthless and spurious. It cannot affirmatively determine which securities are the best to buy.

Although the Corporate Securities Act is based, to some extent, on the theory that a state agency is competent to evaluate, select, and declare by administrative fiat what securities are sound, it is not 
to be hoped that state regulation can achieve anything more than the prevention of fraud and exploitation of ignorance. Where could administrators be recruited who could competently exercise greater power, and actually evaluate all securities? It is believed that no such grant of power is needed or desirable. The Division of Corporations serves a vital and proper function in preventing, at the inception, the issue of obviously worthless and fraudulent securities. It cannot effectively do much more than give the investor, at the start of the race, a fair run for his money. But it is not generally empowered to set up the structures of corporations nor should it superimpose its business judgment, nor its valuations or predictions. The individuals con-cerned must be allowed some freedom of action. Thus in the case of a reorganization where there is a total absence of fraud and there has been complete disclosure and an overwhelmingly favorable vote by the affected security holders, it would appear beyond the province of the Commissioner to substitute his judgment of the exchange values for the informed judgment of the very persons whose direct interests are at stake. ${ }^{97}$

In recapitalization cases and similar situations, a court of equity, generally speaking, will not substitute its judgment for that of the management of the corporation, or assume to appraise the wisdom of any corporate action in the absence of proof of a corrupt bargain or corporate action so patently harmful to the corporation, or its existing security holders, as to indicate an abuse of discretion. ${ }^{98}$ Concededly, the inherent purpose of administrative treatment requires that the administrative agency be clothed with broader discretionary and more flexible power than a court of equity. But no administrative agency

97 Since the completion of this article, the district court of appeal (second dist., div. three) handed down its decision in Transportation Bldg. Co. v. Daugherty (1946) 74 A. C. A. 693 , 169 P. (2d) 470, hearing den. (July 18, 1946). In that case the Commissioner had refused to grant a permit for securities to be issued in a recapitalization, although there had been full disclosure and no shareholder had objected, and the Commissioner had made no finding that the plan was unfair, unjust or inequitable or that fraud would be worked upon the shareholders-and, indeed, the undisputed facts would not have justified any such finding. In sustaining a writ of mandamus ordering the Commissioner to grant the permit, the court stated (74 A. C. A. at 704, 169 P. (2d) at 477):

"The commissioner's act of refusing to issue the permit was, in effect, a veto of the plan by him, on behalf of the holders of the preferred shares. Such supervisory control of the internal affairs of a corporation, however wisely it may be exercised, is not vested in him."

98 See, for a general discussion of the principles and rulcs involved in such cases, the recent decision of the supreme court of Wisconsin in the case of Steven v. Hale-Haas Corp. (1946) ........ Wis. ........ 23 N. W. (2d) 620. 
is so "expert" or so omniscient as to justify the vesting in it of unrestrained licensing powers to be exercised solely in accordance with bureaucratic caprice and without regard to objective standards.

It is interesting to consider the federal securities acts in this connection. The Securities Act of 1933 is purely a disclosure act. The Securities Exchange Act of 1934, except for its provisions with respect to licensing dealers and brokers, is likewise purely a disclosure act. Neither of said acts clothes the Securities and Exchange Commission with any discretionary power to pass on the "soundness" of securities. In contrast, the Public Utility Holding Company Act of 1935 confers broad discretionary power on the Securities and Exchange Commission and requires specific approvals or permits in many instances, and is more nearly akin in theory to the Corporate Securities Act. The standards prescribed in the Holding Company Act of 1935 , while somewhat more objective than those in the Corporate Securities Act, nevertheless grant broad discretionary licensing powers to the Commission. Thus, section 12(d) of the Holding Company Act of 1935 provides, in part, that it is unlawful for any registered holding company to sell any security which it owns of any public utility company in contravention of such rules and regulations or orders regarding the consideration to be received for such sale, fees and commissions, disclosure of interest, and similar matters as the Commission deems necessary or appropriate in the public interest or for the protection of investors or consumers. Despite this sweeping grant of discretionary power, the Securities and Exchange Commission has held, in a competitive bidding case, that while it must consider the overall fairness and equity of a specific transaction, it is not its duty to take over the function of management and to substitute its judgment of what the Commission might consider to be the "precisely" right price at which securities should be sold for a price approved by the management and which falls within a reasonable range of such theoretically "right" price. ${ }^{99}$

99 Holding Company Act of 1935, Release No. 6714 (June 19, 1946) Supplemental Opinion, "In the Matter of Columbia Gas \& Electric Corporation, The Dayton Power and Light Company." In that case a registered holding company, pursuant to preliminary authorization of the Commission, pubhicly invited bids for shares of common stock of its subsidiary. Only two bids were received, and although the winning bid was disappointing, the management after thorough consideration determined to accept it subject to Commission approval. At the hearing before the Commission, the parent of the registered holding company opposed acceptance of the bid on the ground it was too low. The Commission entered its order approving the acceptance of the bid, and in its accompanying Supplemental Opinion stated, in part: 
Reappraisal of the Corporate Securities Act.

The Act is in need of a reappraisal in the light of the decisional law construing it and also because of the experience derived through the federal securities acts.

The Corporate Securities Act, which antedates the first of the series of federal securities acts by almost sixteen years, is, in basic theory, probably the most extremely paternalistic among all existing federal and state securities acts. It is not a disclosure act. Moreover, the Act itself prescribes no definite objective standards. It confers on the administrator practically unlimited discretionary power to grant or deny permits according to his subjective determinations as to what is not "unfair, unjust or inequitable". He is broadly empowered to dispense a Solomon-like justice. In its historical setting, the Act, according to American theory and our traditional devotion to the rule of law, is an early and extreme example of executive justice.

It is a striking paradox that such an extremely paternalistic act should have been evolved in a state that has been famous for its ruggedly individualistic frontier spirit. It was possibly a natural reaction to the mining fever and the wild speculation that characterized California from the gold rush days until well after the period of the Comstock Lode. It is certain that the Act was not passed by a generation who were worshippers of the state, or in an era that was infected by the contemporary niania for state controls.

In actual practice, despite its almost unlimited grant of administrative power, the Act has, in general, been administered with a great

"The central question presented for our decision ... related to 'the consideration to be received' and the overall fairness ... . in the light of that consideration. In passing on that question it was not our function to determine dogmatically the precisely 'right' or 'proper' price and to disapprove any price that deviates from that determination, regardless of the degree of deviation. The pricing of a common stock, particularly ore which has had no previous market history, is not an exact science. The fixing of an appropriate price involves some latitude of judgment as to the factors that may affect the market value of the security and the weight to be assigned to each of those factors ....

"It is not our duty as we see it to take over the function of management by approving or disapproving the transaction solely according to whether we would accept or reject the bid if we were sitting as the management. The performance of our responsibilities under Section 12(d) obviously does not permit exclusive reliance upon the validity or correctness of the management's business judgment in accepting the bid. But in the absence of a persuasive showing that the management was not acting with full information and according to its honest judgment as to the best interests of the selling corporation's stockholders its decision is entitled to substantial weight." 
amount of common sense and a general absence of arbitrariness. California has been generally fortunate in the choice of its Corporation Commissioners.

The Act itself is scarcely a model of master draftmanship. Its terminology is in many respects archaic, slovenly and inept. But in the main, the Act has served its purpose well. It presents very few problems that could not be satisfactorily solved by an enlightened administration or by sound judicial construction. However, as an extreme grant of executive justice, it will remain tolerable only so long as it is administered wisely. Long experience has demonstrated that in the hands of sound administrators its theoretic radicalism is largely innocuous. If, however, its administration should fall into the hands of reforming visionaries, or crusaders with a mission, it could become a serious and intolerable burden on legitimate business.

Assuming a continuation of the type of administration the state has enjoyed, the Act needs no general overhauling or drastic surgery. It could, however, undoubtedly benefit by a cosmetic operation.

First, there is need for a clearer definition of terms, and many of the ambiguities and obscurities in the Act should be resolved. Even the title of the Act is a misnomer. It properly should be the "California Securities and Dealer-Broker Act", since it covers securities issued by individuals, trustees and others, as well as corporate securities, and also regulates dealers and brokers.

Secondly, preliminary transactions between an issuer on the one hand and, on the other, either its promoters and incorporators, or its existing security holders, or underwriters, prior to the actual passing of any consideration or the issuance of any security, should be exempted entirely from the Act. This would properly facilitate certain innocuous preliminary transactions without opening any door to fraud.

Thirdly, the confusion surrounding modifications of outstanding securities and changes of articles of incorporation and indentures, should be removed. Changes which do not involve either a true sale or an exchange of outstanding securities-in which the existing security holders part with nothing of value - should not be subjected to permit requirements.

Fourthly, a limited exemption, along the lines previously indicated, should be granted to foreign issuers in connection with interstate issue transactions which do not involve the raising of new money. 
Finally, a proper statute of limitations, along the lines previously mentioned, should be enacted.

There are, of course, many unresolved problems with respect to civil liability for infractions of the Act. However, it is not believed that any of these problems, or even all of them in the aggregate, are of such urgency as to call for legislative action. Any a priori complete legislative code of liability would entail a major undertaking, and a great deal of controversy. It is believed that all of such problems can be satisfactorily resolved by sound judicial action when and as the occasion arises demanding their solution. 